\title{
ANALISIS PERUBAHAN MOBILITAS TERHADAP PROSES REMEDIASI DAMPAK COVID-19 DI INDONESIA MENGGUNAKAN DATA GOOGLE MOBILITY
}

\author{
(ANALYSIS OF MOBILITY CHANGES FOR THE REMEDIATION PROCESS OF COVID-19 \\ IMPACTS IN INDONESIA USING GOOGLE MOBILITY DATA)
}

\author{
Yoga Dwi Nugroho ${ }^{1}$, Kadek Ari Pratiwi Kasuma² \\ ${ }^{1}$ Badan Pusat Statistik \\ ${ }^{2}$ Badan Pusat Statistik \\ Jl.Dr. Sutomo No.6-8, Jakarta Pusat \\ E-mail: yoga.dwin@bps.go.id, kadek.ari@bps.go.id
}

\begin{abstract}
ABSTRAK
Pandemi COVID-19 merupakan pandemi yang terjadi hampir di semua negara di dunia tidak terkecuali dengan Indonesia. Adanya pandemi ini berdampak tidak hanya pada satu sektor perekonomian saja melainkan multi sektor. Adanya kondisi ini pemerintah perlu melakukan analisis awal untuk menerapkan kebijakan yang tepat terkait penanganan COVID-19 serta proses remediasinya melalui tinjauan perubahan mobilitas. Salah satunya adalah menggunakan big data yang tersedia di internet yaitu, Google Mobility. Google mobility mencerminkan perubahan mobilitas pada enam lokasi yaitu, retail dan rekreasi, toko bahan makanan dan apotek, taman, pusat transportasi umum, tempat kerja, dan area permukiman. Penelitian ini bertujuan untuk memberikan analisis mengenai perubahan apa saja yang terjadi akibat penerapan kebijakan untuk melawan COVID-19 kaitannya dengan mobilitas masyarakat dan dikaitkan dengan kasus konfirmasi positif COVID-19. Selain itu, analisis ini bertujuan untuk membantu proses remediasi dampak COVID-19 melalui tinjauan perubahan mobilitas. Hasil penelitian menunjukkan bahwa kebijakan yang diterapkan pemerintah mempengaruhi penurunan mobilitas masyarakat kecuali area pemukiman. Namun, bertambahnya waktu dan pelonggaran kegiatan dengan adanya new norma/ kasus konfirmasi positif COVID19 semakin meningkat. Adanya analisis korelasi menunjukkan bahwa lima kategori tempat kecuali pemukiman memiliki hubungan yang positif terhadap penambahan kasus positif COVID-19. Sehingga pemerintah perlu bijak dalam menerapkan kebijakan untuk menekan penyebaran dan proses pemulihan (remediasi) dampak COVID-19.
\end{abstract}

Kata kunci: COVID-19, Google mobility, mobilitas, korelasi, remediasi

\section{ABSTRACT}

The COVID-19 pandemic is a pandemic that occurs in almost all countries in the world, including Indonesia. The existence of this pandemic has an impact not only on one economic sector but also for multisectors. With this condition, the government needs to conduct an initial analysis to implement the right policies related to handling COVID-19 and the remediation process through a review of changes in mobility. One of them is using big data available on the internet, namely, Google Mobility. Google mobility reflects changes in mobility in six locations, namely, retail and recreation, grocery stores and pharmacies, parks, public transportation centers, workplaces, and residential areas. This study aims to provide an analysis of what changes have occurred due to the implementation of policies to fight COVID-19 concerning community mobility and associated positive cases of COVID-19. Besides, this analysis aims to help the process of remediating the impact of COVID-19 through a review of changes in mobility. The results showed that the policies implemented by the government affected the decrease in community mobility except for residential areas. However, the increasing time and the relaxation of activities with the new normal confirmed positive cases of COVID-19 are increasing. The existence of a correlation analysis shows that the five categories of places except for settlements have a positive relationship with the addition of positive cases of COVID-19. So that the government needs to be wise in implementing policies to reduce the spread and process of recovery (remediation) of the impact of COVID-19.. 


\section{PENDAHULUAN}

COVID-19 merupakan virus yang pertama kali muncul dan dideteksi di Wuhan, China. Virus ini menyebar ke seluruh dunia dan menimbulkan dampak yang kompleks pada berbagai bidang kehidupan manusia baik itu ekonomi, sosial, pendidikan, sampai yang paling serius kesehatan. Virus ini telah menginfeksi banyak penduduk dunia, sampai dengan 7 Agustus 2020 data worldometer menyebutkan 19.234.205 orang positif terinfeksi COVID-19, 716.465 orang meninggal dunia akibat teronfeksi COVID-19 dan 12.345.201 sembuh. Dari data ini menunjukkan bahwa kasus infeksi COVID-19 masih tinggi tidak terkecuali dengan Indonesia. Adapun kasus COVID-19 di Indonesia sampai dengan periode waktu yang sama kasus positif COVID-19 mencapai 121.226 orang. Rinciannya 38.076 pasien dalam perawatan, 77.557 orang sembuh, dan 5.593 meninggal dunia.

Di samping itu pemerintah Indonesia juga telah menerapkan beberapa kebijakan pembatasan sosial (social distancing) seperti PSBB (Pembatasan Sosial berskala Besar) yang dibagi pada beberapa periode. Selain itu, pemerintah juga menyampaikan adanya kehidupan normal baru (New Normal) dimana pemerintah memberikan kelonggaran pada beberapa aktivitas atau kegiatan secara bertahap mulai tanggal 5 Juni 2020. Namun adanya kehidupan New Normal ini menunjukkan adanya pergerakan kasus terinfeksi positif COVID-19 yang terus meningkat pula. Berdasarkan grafik (Gambar 1) di bawah ini terlihat bahwa memasuki New Normal kasus positif COVID-19 semakin meningkat bahkan pada awal bulan Agustus 2020 kasus positif menyentuh angka 2000 kasus. Tentunya peningkatan kasus ini berkaitan erat dengan perubahan mobilitas masyarakat dalam menjalankan aktivitasnya.

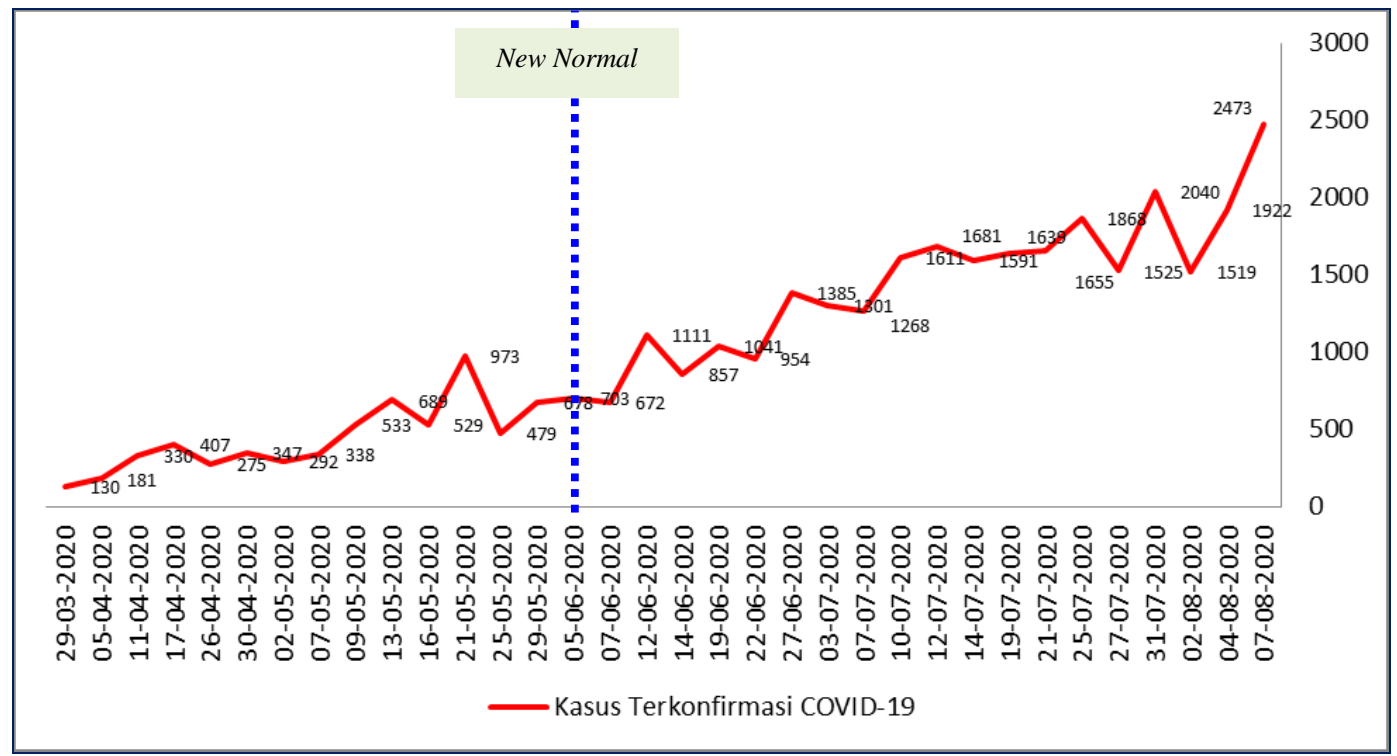

Gambar 40. Grafik kasus terkonfirmasi positif COVID-19 di Indonesia

Salah satu data yang menyediakan pergerakan atau perubahan mobilitas masyarakat di masa pandemi COVID-19 adalah Google Mobility. Google Mobility memberikan gambaran menurut lokasi dan menampilkan perubahan jumlah kunjungan ke tempat-tempat tertentu seperti retail dan rekreasi, toko bahan makanan dan apotek, taman, pusat transportasi umum, tempat kerja, dan area permukiman. Pengelompokan tempat menjadi 6 kategori tersebut merupakan kategori untuk mengelompokkan beberapa tempat dengan karakteristik serupa untuk tujuan panduan pembatasan sosial dan tempat yang beresiko tinggi untuk penyebaran virus COVID-19. Penelitian ini bertujuan untuk memberikan analisis mengenai perubahan apa saja yang terjadi akibat penerapan kebijakan untuk melawan COVID-19 kaitannya dengan mobilitas masyarakat dan dikaitkan dengan kasus konfirmasi positif COVID-19. Selain itu, analisis ini bertujuan untuk 
membantu proses remediasi dampak COVID-19 melalui tinjauan perubahan mobilitas. Adapun metodologi yang digunakan adalah analisis deskriptif dengan grafik, tabel dan korelasi pearson.

Penelitian ini berdasar pada penelitian sebelumnya yang dilakukan oleh Wang dan Yamamoto (2020) yang melakukan peramalan kasus COVID-19 dengan bantuan data aktivitas manusia dari Google Community Mobility Report menggunakan Partial Differential Equation (PDE). Hasil ini diharapkan mampu membantu pemerintah menerapkan tindakan yang diperlukan dan meyakinkan lebih banyak orang untuk mengambil tindakan pencegahan pribadi guna memerangi virus. Model PDE yang dihasilkan akurasi model 94 persen dan adanya keefektifan tindakan pencegahan manusia seperti memakai masker wajah dan mempraktikkan jarak sosial terhadap penurunan kasus COVID-19 di tingkat lokal. Selain itu, Saampi dan Jooste (2020) melakukan penelitian menggunakan data dari Google Community Mobility Report untuk menghitung Google Mobility Index yang digunakan sebagai indikator tingkat pertumbuhan produksi industri bulanan di negaranegara tertentu di Amerika Latin dan Karibia. Hasil menunjukkan bahwa selama pandemi COVID19 pada bulan Maret dan April terdapat penurunan yang signifikan dalam output industri antara 5 dan 7 persenl.

\section{METODE}

Data yang digunakan pada penelitian ini bersumber dari Google Community Mobility Report yang dimulai dari tanggal 29 Maret 2020 sampai 7 Agustus 2020. Google menggunakan data lokasi yang dikumpulkan dari ponsel para penggunanya. Laporan menggunakan data dari pengguna yang mengaktifkan riwayat lokasi di Google. Google Mobility menghasilkan angka presentase perubahan mobilitas yang dibandingkan dengan rata-rata atau nilai tengah (median value) mobilitas pengguna dalam periode lima minggu, yakni 3 Januari hingga Februari 2020. Adapun data perubahan mobilitas yang dikumpulkan adalah sebagai berikut.

1. Retail dan Rekreasi, Toko Bahan

2. Makanan dan Apotek

3. Taman

4. Pusat Transportasi Umum

5. Tempat Kerja

6. dan Area Permukiman

Adapun penelitian ini dianalisis secara deskriptif dengan grafik, tabel dan korelasi pearson. Analisis korelasi pearson ini digunakan untuk mengetahui keeratan hubungan diantara variabel perubahan mobilitas serta variabel perubahan mobili. Adapun rumus dari korelasi Pearson adalah sebagai berikut (Supranto, 2008).

$$
r_{x y}=\frac{n \sum X Y-\sum X \sum Y}{\sqrt{n \sum X^{2}-\left(\sum X\right)^{2}} \sqrt{n \sum Y^{2}-\left(\sum Y\right)^{2}}}
$$

dimana: $r x y=$ nilai korelasi, $X=$ variabel $X$, dan $Y=$ variabel $Y$. Nilai korelasi berkisar antara -1 sampai 1. Semakin besar nilai korelasi maka keeratan hubungan antar variabel semakin erat begitu juga sebaliknya.

\section{HASIL DAN PEMBAHASAN}

Selanjutnya hasil penelitian menunjukkan dengan adanya kebijakan Pembatasan Sosial Berskala Besar (PSBB) yang dilakukan pemerintah, misalnya DKI Jakarta yang dimulai pada tanggal 10 April 2020 menunjukkan adanya perubahan mobilitas yang semakin menurun dengan 5 (retail dan rekreasi, toko bahan makanan dan apotek, taman, pusat transportasi umum, tempat kerja) kategori tempat memiliki penurunan perubahan mobilitas lebih besar dari 20 persen dibandingkan dengan base line. Di sisi lain, perubahan positif terdapat pada area pemukiman karena dengan adanya PSBB dan anjuran pemerintah untuk membatasi kegiatan dan tetap berada di rumah (Stay at Home). 


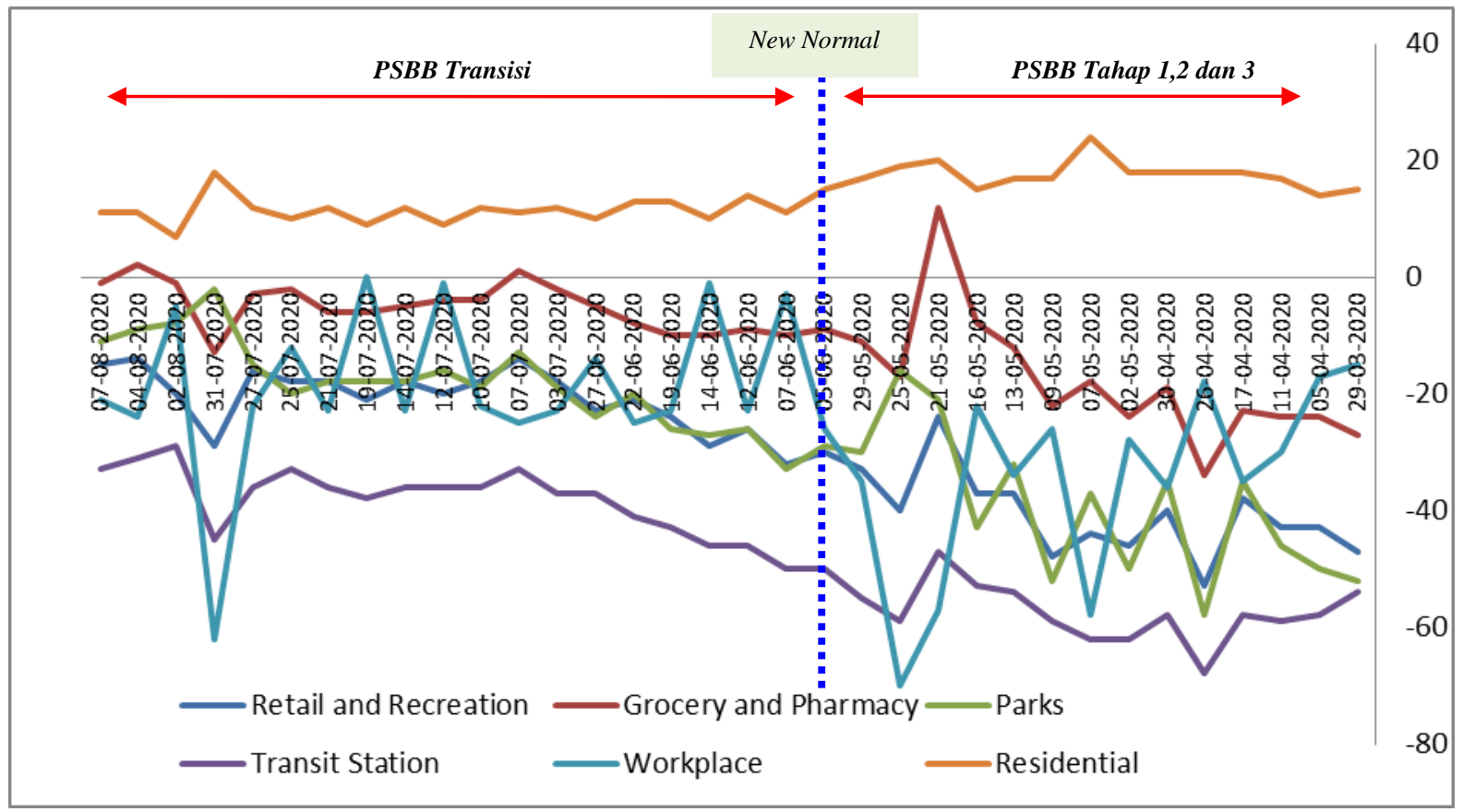

Gambar 2. Grafik perubahan mobilitas untuk 6 kategori tempat

Secara umum kondisi pada PSBB Tahap 1,2 dan 3 menunjukkan bahwa perubahan mobilitas pada pusat transportasi umum, retail dan rekreasi, taman, pusat transportasi umum, tempat kerja yang kecil atau dalam arti lain adalah banyak masyarakat yang tidak melakukan atau membatasi aktivitas atau kegiatan pada kategori tempat tersebut. Jika ditinjau lebih detail, kategori tempat kerja merupakan lokasi dengan penurunan perubahan mobilitas yang cukup signifikan dengan diberlakukan adanya Work From Home pada Minggu ketiga bulan Maret terutama untuk instansi pemerintah dan selanjutnya perubahan mobilitas tetap kecil. Begitupun dengan pusat transportasi umum dimana pemerintah melakukan pembatasan dan protokol kesehatan (jaga jarak, maksimal orang dalam kendaraan), peraturan khususnya dalam masyarakat menggunakan transportasi umum, misalnya stasiun KRL, terminal bus, dan stasiun kereta api serta adanya transportasi umum yang membatasi jam operasional, pembatasan rute dan pembatasan armada yang beroperasi. Namun setelah pemerintah mengumumkan memasuki kondisi normal baru atau ada yang menyebutnya sebagai PSBB Transisi beberpa kategori tempat diberikan kelonggaran pengoperasian sehingga perubahan mobilitas masyarakat semakin meningkat. Hal ini dapat terlihat pada Gambar 2 di atas, semua kategori memiliki trend yang terus meningkat, berbeda dengan 5 kategori tempat sebelumnya untuk pemukiman memiliki trend yang menurun. Hal ini menunjukkan bahwa masyarakat meningkatkan intensitas kegiatannya berada di luar rumah. Namun pelonggaran beberapa tempat yang menunjukkan peningkatan perubahan mobilitas diikuti pula dengan peningkatan pesat konfirmasi kasus positif COVID-19. Selanjutnya, dilakukan uji korelasi pearson untuk mengetahui keeratan hubungan antara perubahan mobilitas beberapa kategori tempat dengan kasus konfirmasi positif COVID-19.

Berdasarkan analisis korelasi dapat terlihat hubungan bahwa adanya kebijakan pembatasan kegiatan pada tempat-tempat yang strategis dan beresiko terhadap penularan infeksi COVID-19 memiliki dampak yang positif terhadap kecepatan penyebaran yang tergambar dalam kasus terkonfirmasi positif. Adapun melakukan kegiatan dari rumah (Stay at home, work from home, school from home) memiliki hubungan yang negatif yang artinya hal ini memperkecil adanya penyebaran virus COVID-19, yang tentunya masyarakat sebisa mungkin melakukan hal ini untuk memutus rantai penyebaran virus. Lebih lanjut analisis ini dapat dijadikan dasar masyarakat dalam melakukan setiap aktivitas, kegiatan di beberapa kategori tempat dengan tetap memperhatikan protokol kesehatan. Selain itu, analisis ini dapat menjadi analisis awal untuk pemerintah menerapkan kebijakan yang tepat terkait dengan pengaturan mobilitas masyarakat agar perubahan mobilitas tetap terpantau dan meminimalisir adanya penyebaran virus COVID-19 dengan memberntuk klaster-klaster baru. 
Tabel 1. Analisis Korelasi

\begin{tabular}{|c|c|c|c|c|c|c|c|}
\hline & $\begin{array}{c}\text { Retail and } \\
\text { Recreatio } \\
\quad n\end{array}$ & $\begin{array}{c}\text { Grocery } \\
\text { and } \\
\text { Pharmac } \\
y\end{array}$ & Parks & $\begin{array}{c}\text { Transit } \\
\text { Statio } \\
n\end{array}$ & $\begin{array}{c}\text { Workplac } \\
e\end{array}$ & Residentia & $\begin{array}{c}\text { Kasus } \\
\text { Terkonfirmas } \\
\text { i COVID-19 }\end{array}$ \\
\hline Retail and Recreation & 1.0000 & & & & & & \\
\hline Grocery and Pharmacy & 0.8935 & 1.0000 & & & & & \\
\hline Parks & 0.8697 & 0.7964 & 1.0000 & & & & \\
\hline Transit Station & 0.9593 & 0.8327 & 0.8224 & 1.0000 & & & \\
\hline Workplace & 0.2774 & 0.1148 & -0.0619 & 0.4041 & 1.0000 & & \\
\hline $\begin{array}{l}\text { Residential } \\
\text { Kasus Terkonfirmasi COVID- }\end{array}$ & -0.7126 & -0.5265 & $\begin{array}{r}-0.4863 \\
\mathbf{0 . 8 4 6}\end{array}$ & -0.8154 & -0.8107 & 1.0000 & \\
\hline 19 & 0.8703 & 0.7358 & 4 & 0.8875 & 0.2110 & -0.6308 & 1.0000 \\
\hline
\end{tabular}

\section{KESIMPULAN}

Dari hasil analisis dapat disimpulkan bahwa terdapat perubahan mobilitas selama diterapkannya kebijakan terkait pemutusan rantai penyebaran kasus COVID-19 pada semua lokasi kegiatan masyarakat yang beresiko. Adanya penerapan PSBB masyarakat memiliki ruang gerak yang terbatas sehingga perubahan mobilitasnya menurun dibandingkan dengan base line. Namun, setelah dilakukan New Normal pelonggaran kegiatan ekonomi mengakibatkan kenaikan terhadap perubahan mobilitas masyarakat. Baik dari awal dilakukannya PSBB atau pembatasan sosial sampai dengan New Normal dan sampai saat ini kasus positif COVID-19 semakin naik. Hal ini menunjukkan laju penyebaran virus yang semakin tinggi di kalangan masyarakat sehingga orang yang terinfeksi semakin. Hasil analisis korelasi menunjukkan hanya dengan Stay at Home mampu meminimalkan penyebaran Virus COVID-19. Tentunya pemerintah perlu menghasilkan kebijakan yang tepat sebagai proses remediasi dampak dari COVID-19 ini.

\section{DAFTAR PUSTAKA}

Bryant, P dan Elofsson, A. (2020). Estimating the impact of mobility patterns on COVID-19 in 11 european countries. Stockholm University and Science for Life Laboratory.

J. Supranto. (2008). Statistika Teori dan Aplikasi, edisi ketujuh. Jakarta: Penerbit. Erlangga.

Sampi, J dan Jooste, C. (2020). Nowcasting Economic Activity in Times of COVID-19: An Approximation from the Google Community Mobility Report. World Bank Group, Macroeconomics, Trade and Investment Global Practice, Policy Research Working Paper 9247.

Wang, H dan Yamamoto, N. (2020). Using Partial Differential Equation with Google Mobility Data to Model COVID-19 in Arizona. School of Mathematical and Natural Sciences Arizona State University 